\title{
Study on herb-drug associations, case of the Fez-Meknes region
}

\author{
Zine El Abidine SAIBARI ${ }^{1}$, Wissal IRAQUI ${ }^{1}$, Hicham MOHTI ${ }^{1}$, Lhoussaine El Rhaffari ${ }^{1}$, and Abdelhamid ZAID ${ }^{1}$. \\ ${ }^{1}$ BIOACTIVES, HEALTH \& ENVIRONMENT laboratory, Moulay Ismail University of Meknes, Morocco.
}

\begin{abstract}
The association of medicinal plants and drugs for therapeutic purposes is not free of adverse effects. In Morocco, this subject remains little known and untreated. A questionnaire study was conducted in the Fez-Meknes region with 250 people between May and December 2019. Structured, face-to-face and telephone interviews were used to collect data. This research focused on the chronically ill population. The Data is analyzed by appropriate statistical software. The study identified 50 species of medicinal plants used in combination with synthetic drugs belonging to 26 botanical families. The results of the survey show that $85.20 \%$ of the users prefer to combine the two types of treatment with drugs and medicinal plants. According to the age and gender of the users, the results showed that age is not a determining factor. Concerning gender, we noted that there is a predominance of women compared to men. The pathologies concerned by the study: diabetes, cardiovascular diseases, gastric diseases, colds and others. The majority of the people questioned are unaware of the undesirable effects and toxicology of the association of plants with synthetic drugs. Indeed, $76.83 \%$ do not know these side effects and $64 \%$ do not know the toxic plants.
\end{abstract}

\section{Introduction :}

The combination of herbal remedies and drugs is a practice followed by people around the world in the treatment of certain diseases. However, this use is not free from undesirable and even toxic effects, and the magnitude of the problem continues to grow [1]. In fact, wrongly considered as products without side effects and without drug interactions, studies have reported cases of intoxication linked to such practices [2], and associated risks have been reported by certain studies [3]. However, most of the research done has focused on laboratory studies that have determined the effects of certain herbal products on drugs metabolizing enzymes. The results thus obtained were extrapolated for the prediction of clinical relevance [1], probably not reflecting "in vivo" reactions. However, the epidemiology of the latter as well as their real consequences remain unknown [4]. Being very numerous and very diverse, the interactions of plants for therapeutic use and certain drugs are not fully understood, and a lack of data is noted in this direction [5].

Morocco, rich in medicinal plants and known for their use, is an excellent example of the present problem. Indeed, few practical studies have looked at the interactions between medicinal plants and drugs [6]. These studies were limited to identifying the effects of the combination of plants and drugs and lack data on Moroccan medicinal plants. The study of such interactions would be very interesting in the development of new therapeutic strategies with fewer side effects [7].

This study focused on medicinal plants from the FezMeknes region and their use in combination with synthetic drugs by the local population. She focused on the use and side effects associated with the combination of herbs and drugs. According to the literature data, bibliographic studies have been carried out, however, to our knowledge, this is the first study to address the use of medicinal plants associated with synthetic drugs, in this part of Morocco. This study will then allow us to select certain associations, which only concern local plants and their impact on health. In addition, a bibliographical study of these plants was also carried out in this work.

\section{Methodology}

\subsection{Study region}

The study was carried out in the region of Fez-Meknes which is located between latitude $34^{\circ} 1 ' 41.9^{\prime \prime}$ north and longitude $5^{\circ} 0^{\prime} 20.3^{\prime \prime}$ west (Fig. 1). Two prefectures (Fez and Meknes) and seven provinces [8].

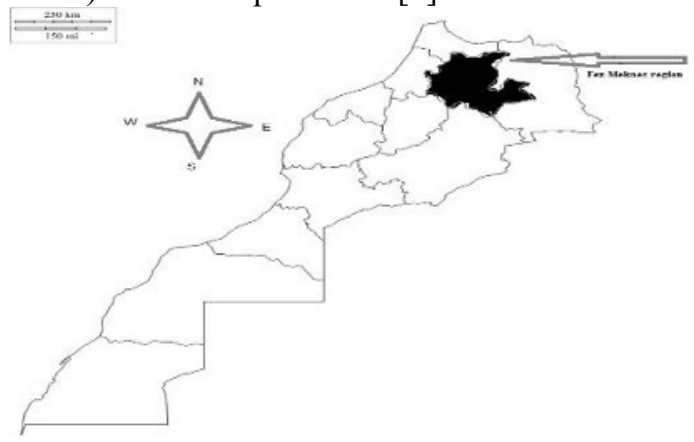

Figure 1: location of the study region

\subsection{Target population}

In the present study, we conducted a survey of a population of 250 people (149 women and 101 men) 
whose age range varied between 18 years and 80 years. The target population has varying levels of literacy (illiterate, primary, secondary and university) and belonged to different socio-professional categories. The people interviewed are mainly those affected by diseases.

\subsection{Conduct of the survey}

The study was carried out in two phases: pre-survey to test the questionnaire and field survey.

The survey was conducted through interviews using a questionnaire with questions focused on medicinal plants and their use in combination with synthetic drugs for therapeutic purposes, the main questions are:

Socio demographic data:

-Age, sex and level of education?

Medical data:

-Which disease did you consult?

Methods of using medicinal plants:

-When you have a health problem, do you use traditional recipes based on medicinal plants associated with drugs?

-Do you know of poisonous plants?

Effects related to the use of plants and plant-drug interactions:

-Do you combine drugs and medicinal plants?

-Are you satisfied with the associated use of synthetic drugs medicinal plants?

-Have you noticed any unwanted effects from the combined use of synthetic drugs and medicinal plants?

If so, what is the observed effect?

-What is the origin of the information about the simultaneous use of synthetic drugs and medicinal plants?

It was carried out for eight months (from May 01, 2019, until December 31, 2019). The interviews were conducted with people met in the souks, in health establishments, in public places, in their homes or contacted by telephone. The questionnaire was explained to all interviewees. For ethical reasons, the objective of the survey was also presented the anonymity of the data is respected.

\subsection{Processing of Survey Data}

The work was carried out in the form of a field study. The choice of this method is based on a descriptive study in order to clarify the problem or behavior still poorly defined or poorly understood as a market study carried out in marketing.

This is a survey based on a questionnaire, intended for the population of the Fez-Meknes region, administered face to face or by telephone.

The survey data was collected daily and processed as follows:

Computer usage, time pressure, and public mistrust are factors that have made us think differently from using paper questionnaires to interview the target population, such as for market studies that require interviews; the responses were recorded directly, manually entered for processing by an appropriate statistical software ,which enables the information collected in the field to be entered, processed and analyzed.
In order to raise the problem of confusion in the vernacular names given to the plant from one locality to another, depending on whether it was in Arabic or Tamazigh. The transliteration into French of Arabic and Tamazight was carried out according to the system adopted by (J .Bellakhdar, 1997) [9] (S .Skalli, 2004) [10] and (L .El Rhaffari, 2002) [11].

\section{Results.}

\subsection{Use of the combination of medicinal plants and synthetic drugs}

The use of medicinal plants in combination with synthetic drugs by the population sample (250 people) was analyzed according to three parameters: sex, age and level of education.

Our survey shows that $92 \%$ of the interviewed population use traditional herbal recipes to treat health problems (Figure 2) and that $85.20 \%$ of the interviewed population prefer to combine plants with medicines. (Figure 3.) The botanical families of medicinal plants used in combination with drugs are Lamiaceae 38\%, Apiaceae 16\%, Asteraceae 10\%, Fabaceae 9\%, Rutaceae 9\%, Myrtaceae 9\%, Poaceae 6\%, Others 3\%. (Figure 4).

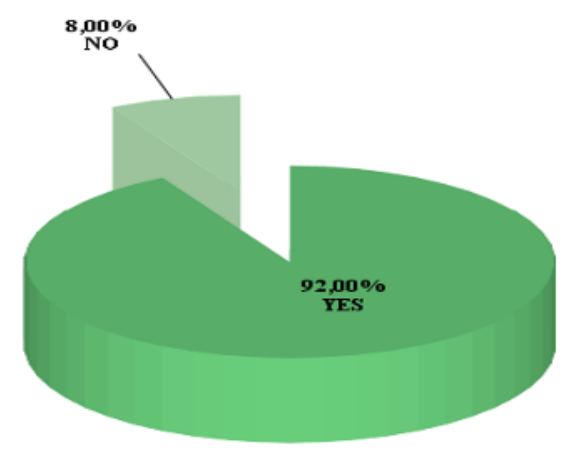

Figure 2: The use frequency of traditional receipts based on medicinal plants

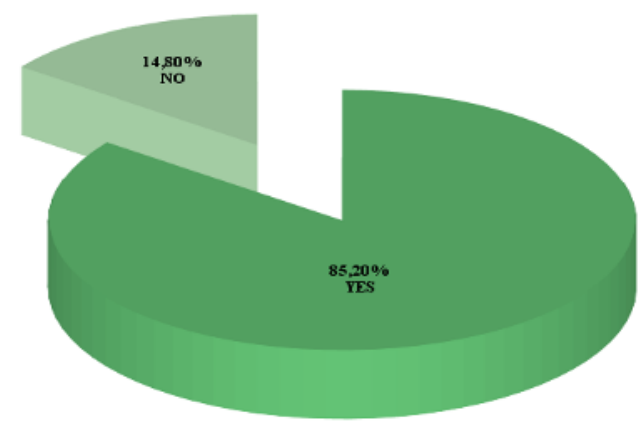

Figure 3: Association between medicinal plants and synthetic drugs 


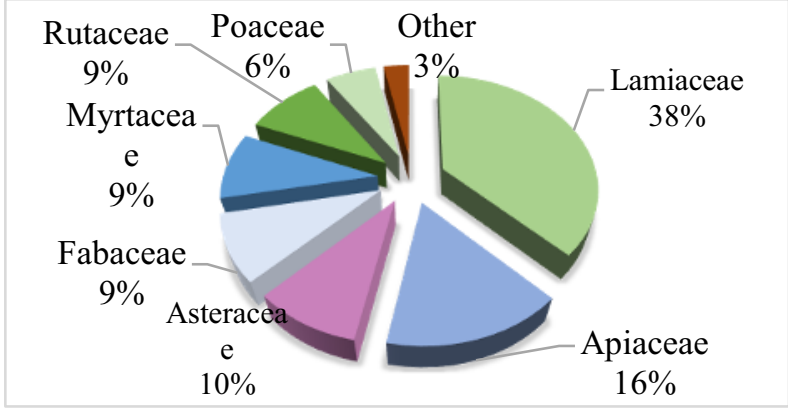

Figure 4: Taxonomic repartition of the medicinal plants species used in association with synthetic drugs

\subsubsection{Distribution of users by sex}

Analysis of the results shows that women $49,60 \%$ use this combination more than men $35.60 \%$ (Figure 5).

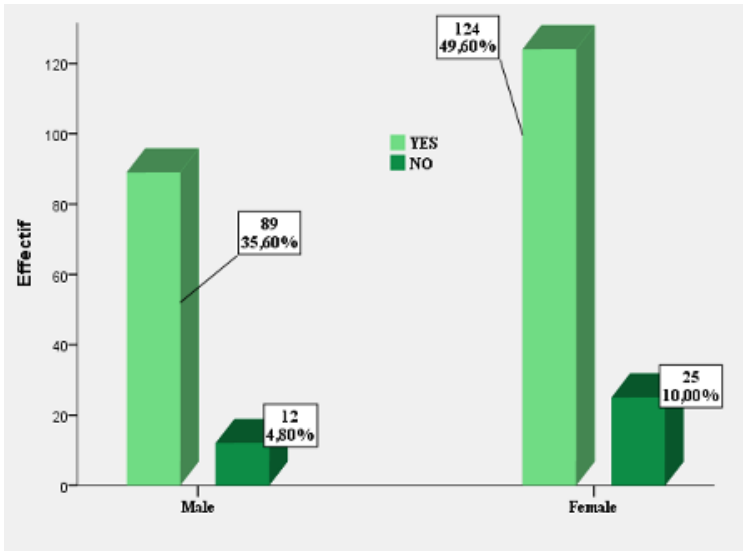

Figure 5: The use frequency of medicinal plants in association with synthetic drugs by sex

\subsubsection{Distribution of users according to age}

Medicinal plants associated with drugs are used by all age groups of our population, as shown in (Figure 6).

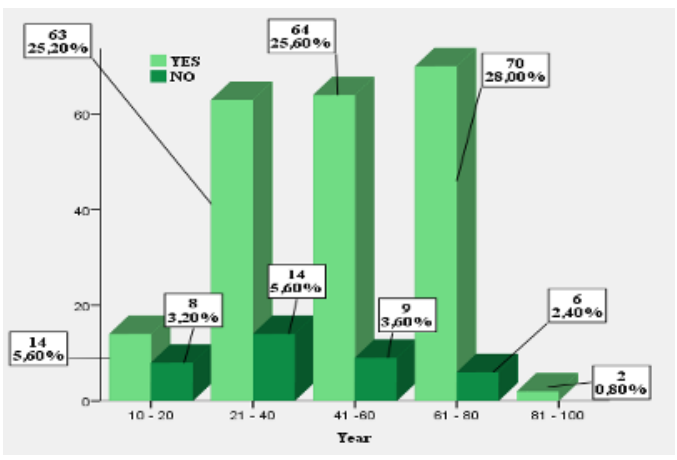

Figure 6: The use frequency of medicinal plants in association with synthetic drugs by Age

\subsubsection{Distribution of users according to literacy levels}

According to the results, the use of medicinal plants in combination with drugs is also noted in all our sampling, regardless of the level of study (Figure 5). However, people with just primary education seem the least adept at 'such a practice $(8.80 \%)$ versus those with a high level of academic education $(32.40 \%)$.

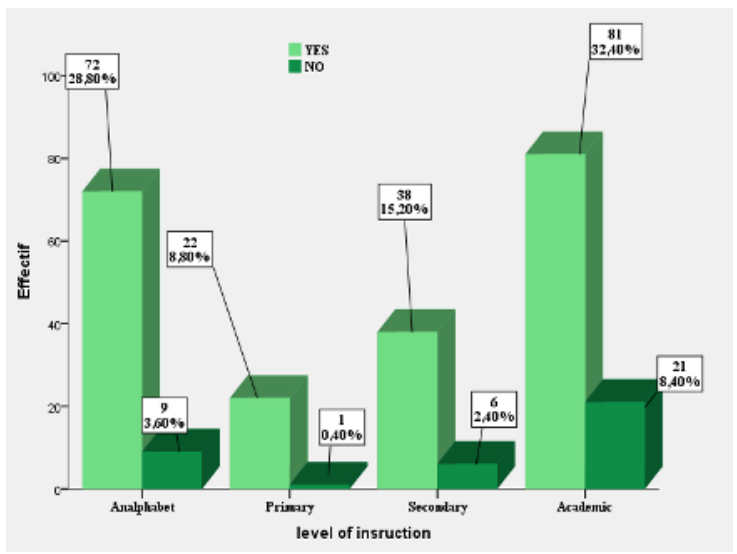

Figure 7: The use frequency of medicinal plants in association with synthetic drugs by level of instruction

At the same time, we were interested in the unwanted effects and pathologies for which the local population uses the combination of medicinal plants with synthetic drugs.

\subsection{Use of medicinal plants in combination with synthetic drugs: causes and unwanted effects}

\subsubsection{Causes of the use of medicinal plants in combination with synthetic drugs}

Analysis of the results shows that the causes of the use of medicinal plants in combination with synthetic drugs mainly concern cardiovascular disease, diabetes, and the common cold (Figure 8).

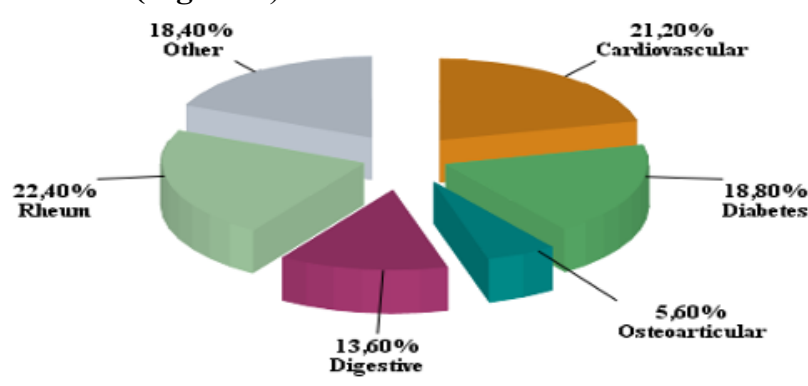

Figure 8: Predominantly pathology at the last consultation

\subsubsection{Unwanted effects observed by interviewees of associated use, synthetic drugs, medicinal plants}

Analysis of the results shows that $3.66 \%$ experienced nausea; $1.63 \%$ of hemorrhages; $5.26 \%$ of dizziness; $2.03 \%$ of rashes and $76.83 \%$ do not know; $10.6 \%$ other signs (Figure 9). 


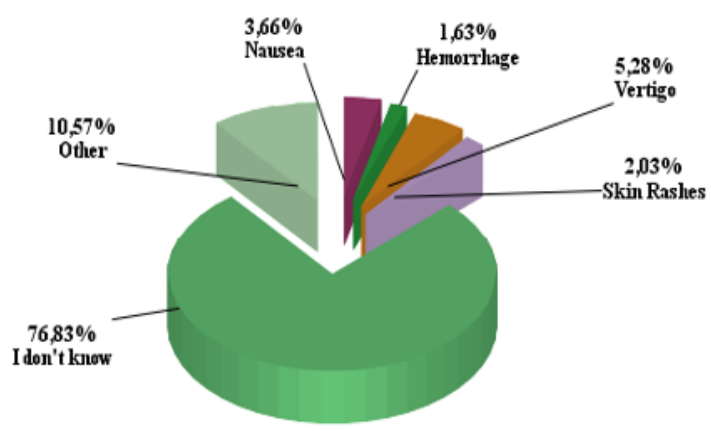

Figure 9: Frequency of secondary effects associated with the combination of medicinal plants and synthetic drugs

3.2.3 Knowledge of unwanted effects, of the use of the combination of synthetic drugs and medicinal plants

According to the results, $48.40 \%$ of the surveyed population did not know about the unwanted effects of the combined use of synthetic drugs and herbal medicines and $28.80 \%$ did not know about them (Figure 10).
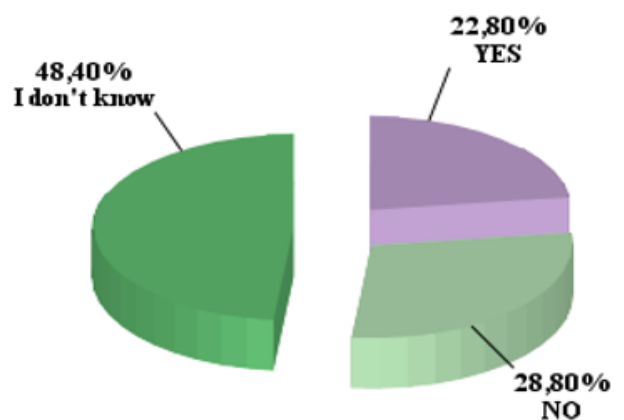

Figure 10: Frequency of knowledge of secondary effects associated with the combination of medicinal plants and synthetic drugs

\subsubsection{Knowledge of poisonous plants}

Analysis of the results shows that $63.7 \%$ of the population interviewed did not know about poisonous plants (Figure 11).

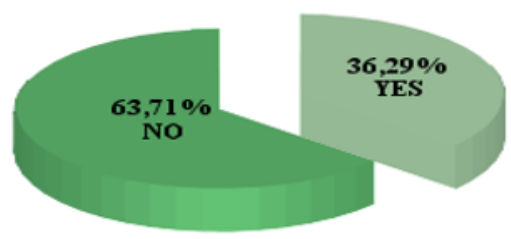

Figure 11: knowledge of toxic plants

In this study, we were also interested in other opinions of the users interviewed: the association between plants and drugs, satisfaction and the origin of the information.

\subsubsection{Satisfaction between medicinal plants and synthetic drugs}

Analysis of the results shows $57.09 \%$ are satisfied with this combined use (Figure 12).

The analysis also shows that the origin of the information of the associated use between drugs and medicinal plants comes from the experience of the other $66.29 \%$, and that $23.21 \%$ of the information comes from the parents (Figure 13).

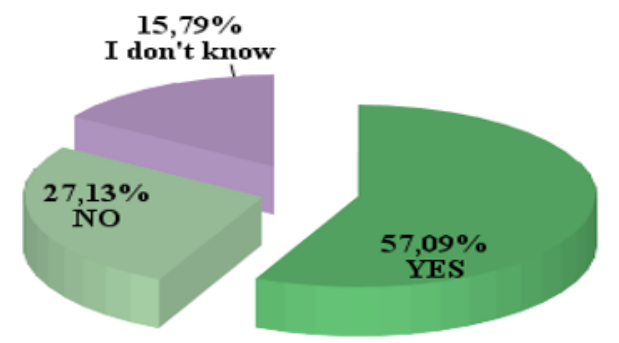

Figure 12: satisfaction with the use of medicinal plants used in combination with medicines

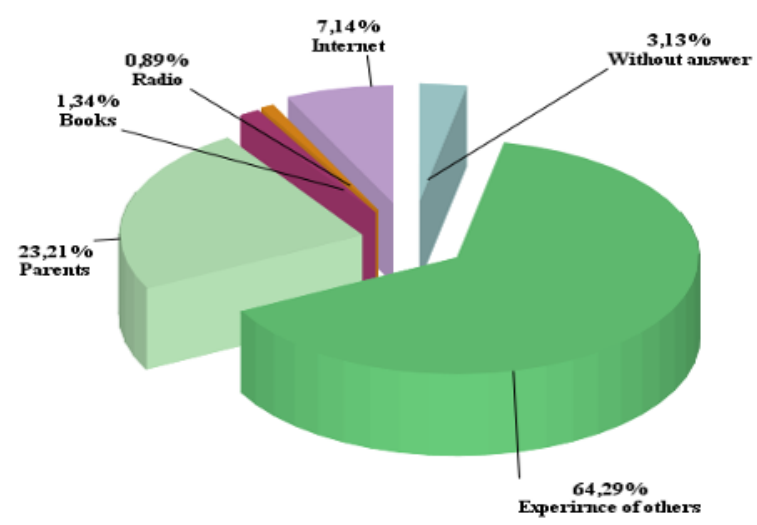

Figure 13: Source of information

\subsubsection{Table relating to the plant species used by the interviewees in combination with drugs.}

During this investigation also to the species associated with the drugs of the users interviewed:

In this table, the information relating to the species used in combination with synthetic drugs has been summarized. Their transliteration into French from Arabic and Tamazight was carried out according to the system adopted by (J .Bellakhdar, 1997) [9] (S .Skalli, 2004) [10] and (L.El Rhaffari, 2002) [11].

We found 50 species belonging to 26 Families (Lamiaceae 12 species; Apiaceae 05 species; Asteraceae: 3 species; Fabaceae: 3 species; Myrtaceae 03 species; Rutaceae 03 species; Poaceae 2 species; the others a single species). 
Table 1: plant species used in combination with synthetic drugs and their families

\begin{tabular}{|c|c|c|c|c|c|}
\hline Scientific Name & Family & $\begin{array}{c}\text { Vernacular } \\
\text { Name/French }\end{array}$ & $\begin{array}{l}\text { Vernacular } \\
\text { Name/Arabic }\end{array}$ & $\begin{array}{c}\text { Vernacular } \\
\text { name/ } \\
\text { amazigh } \\
\end{array}$ & $\begin{array}{c}\text { Referenc } \\
\text { es }\end{array}$ \\
\hline Anthemis cotula L. & Asteraceae & camomille & bâboûnj & & {$[10],[11]$} \\
\hline $\begin{array}{l}\text { Argania spinosa (L.) } \\
\text { Skeels }\end{array}$ & Sapotaceae & arganier & argân & Aba'ou & {$[10]$} \\
\hline $\begin{array}{l}\text { Artemiisia herba alba } \\
\text { Asso }\end{array}$ & Asteraceae & Armoise blanche & chîh & girsî & {$[10]$} \\
\hline Allium Sativum L. & Alliaceae & Ail cultivé & tûm, tûma & tiskert & [9] \\
\hline \multirow[t]{2}{*}{ Thymus vulgaris L. } & \multirow[t]{2}{*}{ Lamiaceae } & \multirow[t]{2}{*}{ Thym } & Z'îtra & azoui & \multirow[t]{2}{*}[10]{} \\
\hline & & & Zaa'tar & azoukenni & \\
\hline Camelia thea Link & Camelliaceae & thé & atây & tây & {$[10]$} \\
\hline $\begin{array}{l}\text { Chenopodium album L., } \\
\text { C.ambrosoides L. }\end{array}$ & Chénopodiaceae & chénopode & mkhinza & aggaouit & {$[10]$} \\
\hline Glycyrrhiza glabra L. & Fabaceae & réglisse & arq souss & & [9] \\
\hline $\begin{array}{l}\text { Lavendula officinalis } \\
\text { Chaix }\end{array}$ & Lamiaceae & Lavande vraie & khuzâma fassiya & iguiguiz & {$[10]$} \\
\hline Rosmarinus officinalis $L$. & Lamiaceae & romarin & azir & aklel & $\begin{array}{l}{[10]} \\
{[11]}\end{array}$ \\
\hline Foeniculum vulgare & Apiaceae & grains d'anis & Nafaâ & & [9] \\
\hline $\begin{array}{l}\text { Pennisetum typhoides } \\
\text { (Burm.) Stapf.et Hubb L. }\end{array}$ & Poaceae & Maîs noir & el-labd & bechnâ & {$[10]$} \\
\hline $\begin{array}{l}\text { Phalaris minore Retz, } \\
\text { P.canariensis L., }\end{array}$ & Poaceae & alpiste & ddmiya & tiggurrâmin & {$[10]$} \\
\hline Peganum harmala L. & Zygophyllaceae & Rue sauvage & $\begin{array}{l}\text { Harmel ess'harî } \\
\text { (graine) }\end{array}$ & & $\begin{array}{l}{[10]} \\
{[11]}\end{array}$ \\
\hline Corrigiola telephiifolia & Caryophyllaceae & Corrigiole & Sargina & tassergint & [9] \\
\hline Origanum élongatum & Lamiaceae & Origan & za'tar & & [9] \\
\hline Mentha pulegium $L$. & Lamiaceae & Menthe pouliot & fliyoû & afilgou & {$[10]$} \\
\hline Marva parviflora $L$. & Malvaceae & mauve & baqoûla & abejjir & {$[10]$} \\
\hline Sativa officinalis $L$. & Lamiaceae & sauge & sâlma & mr'ennebo & {$[10]$} \\
\hline Origanum majorana L. & Lamiaceae & Marjolaine & $\begin{array}{l}\text { Merdeddouch } \\
\text { merdedûs }\end{array}$ & & [9] \\
\hline Artemisia absinthium & Astéraceae & Absinthe & Chhiba & & [9] \\
\hline Mirtus communis & Myrtaceae & Myrtille & Rhaihane & & [19] \\
\hline $\begin{array}{l}\text { Trigonella foenum- } \\
\text { graecum }\end{array}$ & Leguminoseae & Fenugrec & 1-helba & tifidas & [9] \\
\hline $\begin{array}{l}\text { Eucalyptus } \\
\text { globulus Labill. }\end{array}$ & Myrtaceae & Eucalyptus, & $\begin{array}{l}\text { kalitûs } \\
\text { kalibtûs }\end{array}$ & & [9] \\
\hline Glycine max (L.) Merr & Fabaceae & Soja & Soja & & [9] \\
\hline Citrus sinensis L & Rutaceae & Oranger & & & {$[13]$} \\
\hline $\begin{array}{l}\text { Eugenia } \\
\text { caryophyllata } \\
\text { Thumb } \\
\end{array}$ & Myrtaceae & giroflier & $\begin{array}{l}\text { qoronfel } \\
\text { 'ûd nuwwâr }\end{array}$ & & [9] \\
\hline $\begin{array}{l}\text { Euphorbia echinus } \\
\text { Hook.f. \& Coss. }\end{array}$ & Euphorbiaceae & euphorbe cactoide & ddagmûs & & $\begin{array}{l}{[9]} \\
{[11]}\end{array}$ \\
\hline
\end{tabular}




\begin{tabular}{|c|c|c|c|c|c|}
\hline Curcuma longa & Zingibéraceae & curcuma & kharkoum & & [10] \\
\hline Ruta graveolens $L$. & Rutaceae & Rue des jardins & Fîdjel & & [19] \\
\hline Mentha spicata $L$. & Lamiaceae & Menthe verte & na'na & & [9] \\
\hline Pimpinelle anisum L. & Apiaceae & Anis vert & habbat halâwa & & [9] \\
\hline Lippia citriodora & Verbenaceae & Verveine & Lwiza & & [9] \\
\hline Ceratonia selliqua $L$. & Fabaceae & Caroubier & $\begin{array}{l}\text { Kharoub, l- } \\
\text { herrôb }\end{array}$ & tikidit & [9] \\
\hline \multirow[t]{2}{*}{ Opuntia fucus india Mil } & Cactaceae & Figuier de Barbarie, & hendi, tahendit & Taknârit & [9] \\
\hline & & Cactus raquette & & & [9] \\
\hline Capparis spinosa & Capparidaceae & Câprier & Alkabar, Kabâr & & $\begin{array}{l}{[11],} \\
{[12]}\end{array}$ \\
\hline $\begin{array}{l}\text { Mentha } \\
\text { suaveolens Ehrh. }\end{array}$ & Lamiaceae & $\begin{array}{l}\text { Menthe à feuilles } \\
\text { rondes }\end{array}$ & $\begin{array}{l}\text { Mchachro, } \\
\text { marseta }\end{array}$ & & [9] \\
\hline $\begin{array}{l}\text { Cinnamomum, cassia } \\
\text { Blume }\end{array}$ & Lauraceae & Cannellier & qarfa, 1-qarfa & & [9] \\
\hline Aloe succotrina All & Asphodelaceae & Aloès & $\begin{array}{l}\text { sabra } \\
\text { sibr, siber, sabr }\end{array}$ & & [9] \\
\hline Marrubium vulgare $L$. & Lamiaceae & Marrube blanc & $\begin{array}{l}\text { rnerrîwut, } \\
\text { merrîwa }\end{array}$ & îlzi & [9] \\
\hline Cuminum cyminum L. & Apiaceae & Cumin & kemmûn & & [9] \\
\hline $\begin{array}{l}\text { Citrus maxima (Burm.) } \\
\text { Merr. }\end{array}$ & Rutaceae & Pamplemoussier & & & {$[13]$} \\
\hline Citrus auranticum & Rutaceae & Oranger amer & narandj & & [13] \\
\hline \multirow[t]{2}{*}{ Crocus sativus $L}$. & Iridaceae & safran vai & za'afran hôrr & & [9] \\
\hline & & Crocus cultivé & & & [9] \\
\hline Linum usitatissium L & Linaceae & lin cultivé & zenî'at 1-kenân & & [9] \\
\hline Coriandrum sativum $L$. & Apiaceae & coriandre & Qezbor & & [9] \\
\hline $\begin{array}{l}\text { Petroselinum sativum } \\
\text { Hoffm. }\end{array}$ & Apiaceae & persil & ma'adnûs & & [9] \\
\hline Ammi visnaga (L.) Lam & Apiaceae & ammi & Bachnikha & & $\begin{array}{l}{[9]} \\
{[11]}\end{array}$ \\
\hline Punica granatum L. & Punicaceae & Grenadier & $\begin{array}{l}\text { er-rurnmân, } \\
\text { tarommânt }\end{array}$ & & [9] \\
\hline $\begin{array}{l}\text { Zingeber } \\
\text { officinalis Roscoe }\end{array}$ & Zingiberaceae & gingembre & $\begin{array}{l}\text { Zanjabil ou } \\
\text { skinjbir }\end{array}$ & & {$[18]$} \\
\hline
\end{tabular}

\section{Discussion}

The present study lists the medicinal plants used in association with synthetic drugs in the Fez-Meknes region, their use, and the determination of the side effects linked to such use.

The results of the survey carried out in the FezMeknes region show that the interviewed population is made up of different age groups, with varying levels of literacy. We noted that women $49,60 \%$ use this combination more than men $35.60 \%$.This can be explained by the fact that women are more familiar with medicinal plants than men are.

This survey clearly showed that the combined use of medicinal plants and drugs is widely practiced by the population to treat various human diseases and that a significant number of participants $(85.20 \%)$ prefer to combine the two types of medicine (more than 50\%). The same conclusion was postponed by the study conducted by Moussaoui and al [14].

The main diseases treated by the combination of plants with synthetic drugs concern the cardiovascular system, diabetes, osteoarticular joints and the common cold. These results are in part consistent with other studies carried out in France and America [15] [16].

The comparison of the results shows that the main adverse effects observed by the interviewees of the combined use of synthetic drugs and medicinal plants are as follows: nausea, hemorrhages; dizziness; Rashes. This is compatible with observations and conclusions from other studies carried out in this context, Williamson E studies, and Skalli S et all study[ 17] [6].

In addition, we noted that $48.40 \%$ of the interviewed population did not know the unwanted effects of the combined use of synthetic drugs and medicinal plants and $28.80 \%$ did not know about them. This reflects the risk incurred by the population in the use of this combination. 
At the same time, among the families of plants identified, we note the Lamiaceae (38\%), the Apiaceae $(16 \%)$, and the Fabaceae $(9 \%)$. The frequency of these families has also been mentioned by previous studies carried out both throughout Morocco and in Mediterranean countries [18]. Some species such as Origanum compactum, Mentha pulegium, and Rosmarinus officinalis, cited by previous studies in different regions of Morocco [14], have not been mentioned for their associated uses with drugs.

In fact, the target population often uses plant species whose toxicity they ignore: $63.7 \%$ of the population interviewed do not know about poisonous plants, with a frequency of more than $60 \%$.

As well as the origin of the information of the associated use between drugs and medicinal plants comes from the experience of others, $66.96 \%$ and $23.21 \%$ of parents.

\section{Conclusion}

The information collected in the survey carried out in the FEZ-Meknes region shows that the associated use between plants and medicine is requested by the local population in order to treat diseases $85.2 \%$ and $57.09 \%$ are satisfied with this use associate.

The study also shows that there are risks following this association, which are mostly ignored, $48.40 \%$ do not know the unwanted effects and $28.80 \%$ do not know them, which represents a danger to their health.

Knowledge based on the transmission of information relating to the subject, in an unscientific way since the origin of the information of the associated use between drugs and medicinal plants comes from the experience of others $66,96 \%$, and $23.21 \%$ comes from parents. Encourages researchers and experts to establish databases on possible interactions between plants and drugs for all medicinal plants used for therapeutic purposes and to mention their toxicity, more particularly in Morocco.

Awareness and health education are needed in order to mitigate the dangers incurred by the unscientific use of this mixing of uses.

Develop more research on the impact of this association and its interactions on human health, or to innovate new beneficial therapies, for the plants used in the Fez-Meknes region and in Morocco.
5. MUMONS, Medicinal Plants and Drugs: Combinations at Risk? By Antonelle Pardo (2018)

https://www.youtube.com/watch?v=x9i1vZT ARmQ .

6. S. Skalli, A. Zaid, and R. Soulaymani, Ther. Drug Monit. 29, 679 (2007)

7. A. Singh and K. Zhao, in Neurobiol. Chin. Herb Med., edited by B. Y. Zeng and K. Zhao (Elsevier Academic Press Inc, San Diego, 2017), pp. 197-232(2017)

8. https://fesmeknesinvest.ma/fr/presentation_region

9. J. Bellakhdar, Contribution to the study of The Traditional Pharmacopoeia In Morocco: The Current Situation, The Products, The Sources Of Knowledge (Ethnopharmacological Field Survey Carried Out From 1969 To 1992), Doctoral Thesis, Metz (1997)

10. S .Skalli . Contribution to the development of plant toxicology by application of new technologies, study of scientific denominations and vernacular names, acute toxicity of plants in Morocco and approach to the clinical toxicity of glue thistle. Doctoral Thesis .Fsm, Umi, 216 (2004)

11. L. El Rhaffari and A. Zaid, in Sources Savoir Aux Médicam. Futur, edited by J. Fleurentin, G. Mazars, and J.-M. Pelt (IRD Éditions, Marseille, 2014), pp. 293-318 (2014)

12. Anonymous. Table relating to the List of PMA species identified as potential for the region, Meknes-Tafilalet. Social Development Agency (ADS) study; (2011).

13.https://www.telabotanica.org/search/Citrus+au ranticum $+\% \mathrm{E} 2 \% 80 \% 8 \mathrm{E} /$

14. F. Moussaoui, T. Alaoui, and S. Aoudry, Am. J. Plant Sci. (2014)

15. N. Sandra and S. Charline, 206 (2011)

16. J. Boullata, Nutr. Clin. Pract. Off. Publ. Am. Soc. Parenter. Enter. Nutr. 20, 33 (2005)

17. E. M. Williamson, Drug Saf. 26, 1075 (2003)

18. M .El Houari and Al. A survey of medicinal plants used by herbalists in Taza (Northern Morocco) to manage various ailments. J. Mater. Environ. Sci. 9, 1889 (2018)

\section{References}

1. P. S. Fasinu and G. K. Rapp, Front. Oncol. 9, 1356 (2019)

2. D. G. Bailey, J. D. Spence, C. Munoz, and J. M. Arnold, Lancet Lond. Engl. 337, 268 (1991)

3. C. Gouws and J. H. Hamman, Expert Opin. Drug Metab. Toxicol. 16, 165 (2020)

4. S. Mouly, M. Morgand, A. Lopes, C. LloretLinares, and J.-F. Bergmann, Rev. Med. Interne 36, 530 (2015) 